\title{
Comparison of kidney tissue and ovarian fluid from broodstock Atlantic salmon for detection of Renibacterium salmoninarum, and use of SKDM broth culture with Western blotting to increase detection in ovarian fluid
}

\author{
S. G. Griffiths ${ }^{1}$, K. Liska ${ }^{2}$, W. H. Lynch ${ }^{2}$ \\ ${ }^{1}$ Research and Productivity Council, Fredericton, New Brunswick, Canada E3B 6Z9 \\ ${ }^{2}$ Department of Biology, University of New Brunswick, Fredericton, New Brunswick, Canada E3B 6 E1
}

\begin{abstract}
As part of a screening program to reduce the vertical transmission of bacterial kidney disease (BKD) in 1992, kidney tissue and ovarian fluid from subclinically affected broodstock Atlantic salmon Salmo salar L. were assayed for the presence of Renibacterium salmoninarum. Of the methods used, culture on selective kidney disease medium (SKDM) agar identified the highest number of samples positive for $R$. salmoninarum followed by the indirect fluorescent antibody technique (IFAT). The comparatively low sensitivities of an enzyme-linked immunosorbent assay (ELISA) and Western blot assay reflected the low levels of $R$. salmoninarum in most infected samples. Also, for many individual fish sampled, $R$. salmoninarum was detected either in the kidney tissue or in ovarian fluid but not in both. In an attempt to increase the level of detection, a method involving incubation of ovarian fluid cellular debris in SKDM broth followed by Western blotting was used to screen ovarian fluids in 1993. This relatively simple procedure identified more positive samples than either of the established methods of SKDM agar culture or IFAT Although it increased the total numbers of positive samples identified by $32 \%$, incomplete correlation among methods was observed. Therefore, to ensure that the maximum number of positive samples is detected, it is advisable to use a combination of these methods.
\end{abstract}

KEY WORDS: BKD · Detection · Atlantic salmon

\section{INTRODUCTION}

Bacterial kidney disease (BKD) caused by the Grampositive bacterium Renibacterium salmoninarum continues to be a problem for salmonid aquaculture on an international basis (Evenden et al. 1993). In eastern Canada, the disease affects chiefly 2 and 3 yr searaised Atlantic salmon Salmo salar L. It is not that uncommon to identify infection in $30 \%$ or more of market or broodstock fish by culture from kidney tissue, the majority of which show no obvious external or internal clinical signs of disease (Lovely et al. 1994). The local experience is that BKD usually causes a lowlevel mortality although serious losses may occur over short periods. The affected individuals generally exhibit little if any external clinical signs, but upon internal examination the pathology may include grossly convex greyish kidney tissue and white granulomatous lesions in all major internal organs.

Due to lack of effective chemotherapy and the absence of a vaccine, screening of reproductive fluids from broodstock for Renibacterium salmoninarum is considered to be the most effective means of avoiding transmission of the pathogen. The ovarian fluid surrounding eggs from female fish is collected for this purpose. $R$. salmoninarum cells present in ovarian fluids are able to passively infect eggs intra ovum (Evelyn et al. 1984, 1986, Lee \& Evelyn 1989). In con- 
trast, the reproductive fluid of male broodstock is not believed to have a significant effect on the vertical transmission of $\mathrm{BKD}$, even when the milt is heavily contaminated (Evelyn et al. 1986).

The indirect fluorescent antibody technique (IFAT) (Bullock \& Stuckey 1975) and culture on selective kidney disease medium (SKDM) agar (Austin et al. 1983) are the most common methods for screening ovarian fluids in eastern Canada. However, IFAT is regarded as a relatively insensitive method (unless combined with membrane filtration; Elliot \& Barila 1987) when compared to culture on SKDM agar (Armstrong et al. 1989). Furthermore, whereas culture is the more relevant and sensitive method for the detection of viable Renibacterium salmoninarum, incubation for approximately $6 \mathrm{wk}$ is required before individual colonies can be observed. Other authors report that incubation for up to $19 \mathrm{wk}$ may be required for the successful culture of some isolates (Benediktsdottir et al. 1991).

In the first part of our study, conducted in 1992, kidney tissue and ovarian fluid from broodstock Atlantic salmon showing no signs of BKD were assayed by various methods to detect Renibacterium salmoninarum [SKDM agar culture, IFAT, an enzyme-linked immunosorbent assay (ELISA), and Western blotting]. The initial purpose was to compare the methods for their ability to detect the pathogen in subclinically infected broodstock. Because negative ovarian fluid results were obtained for a high percentage of fish that proved positive by culture of kidney tissue, we suspected that some ovarian fluids containing low levels of $R$. salmoninarum had escaped detection. Therefore, a method combining growth enrichment in SKDM broth with Western blotting was incorporated into a subsequent screening of ovarian fluids in 1993 in an effort to confirm this suspicion. The hypothesis was that small numbers of $R$. salmoninarum might be present in concentrated ovarian fluid cellular debris which could be incubated in SKDM broth. This might permit growth of the pathogen to a level where Western blots of the cultured material would reveal the presence of a diagnostic marker antigen (the p57 protein; Wiens \& Kaattari 1991) for $R$. salmoninarum. The results obtained using this method were compared to those obtained with established methods of SKDM agar culture and IFAT.

\section{MATERIALS AND METHODS}

Collection of ovarian fluid and kidney tissue. Ovarian fluid samples were obtained in November 1992 from 200 gravid female Atlantic salmon held at a farm (Farm D) in the Bay of Fundy, New Brunswick,
Canada. Under field conditions, eggs and ovarian fluid from individual fish were collected by industry personnel in clean, non-sterile containers. Ovarian fluid samples were then immediately collected from below the surface of the liquid using $3 \mathrm{ml}$ sterile vacutainer tubes with needle units (Becton Dickinson Co., Rutherford, NJ, USA). The samples were stored overnight at $4^{\circ} \mathrm{C}$ prior to processing.

Ovarian fluid samples $(1.5 \mathrm{ml})$ were sedimented at $2000 \times g$ for $10 \mathrm{~min}$ in a centrifuge (Model HN, International Equipment Co., Needham Hts., MA, USA) and the pellet washed with $1.5 \mathrm{ml}$ phosphate buffered saline ( $\mathrm{pH}$ 7.2). After decanting, the pellet was suspended in the fluid (approximately 50 to $100 \mu \mathrm{l}$ ) remaining in the centrifuge tube and $5 \mu \mathrm{l}$ was applied to glass slides, fixed with acetone, and stained for IFAT (Bullock \& Stuckey 1975) using a polyclonal antiserum prepared in this laboratory (Griffiths \& Lynch 1991). A sterile cotton swab was inserted into the suspended pellet and used to spread the sample over the surface of SKDM agar plates (Austin et al. 1983). The SKDM agar plates were incubated at $15^{\circ} \mathrm{C}$ for $6 \mathrm{wk}$, and growth appearing was confirmed as Renibacterium salmoninarum by Western blotting (Griffiths et al. 1991, Lovely et al. 1994). Aliquots of the (non-centrifuged) ovarian fluid samples were assayed by an ELISA (K-Dtect) as per the manufacturer's instructions (DiagXotics Inc., Wilton, CT, USA)

Kidneys were removed from the above fish, stored at $4{ }^{\circ} \mathrm{C}$ overnight, and homogenized as previously reported (Olivier et al. 1992). Resulting homogenates were assayed for Renibacterium salmoninarum by the IFAT, by culture on SKDM agar, by ELISA as above, and by the Western blot assay. The polyclonal antiserum, previously described, was used for the IFAT and the Western blot assay.

Analysis for Renibacterium salmoninarum in ovarian fluid samples. Ovarian fluid samples (total of 601) were collected in November 1993 from gravid female Atlantic salmon held at 6 separate farms in the Bay of Fundy and subjected to analysis by IFAT and culture on SKDM agar as described above.

In addition, the ovarian fluid samples were screened by a growth enrichment step followed by Western blotting, as described below. Separate aliquots $(1.5 \mathrm{ml})$ of each ovarian fluid sample were sedimented as described previously and the supernatants decanted. The pellets were suspended in $3 \mathrm{ml}$ of SKDM broth and incubated at $15^{\circ} \mathrm{C}$ for $3 \mathrm{wk}$ without agitation. The broths were then sedimented, and the pellets were suspended in $200 \mu \mathrm{l}$ of electrophoresis sample buffer (Laemmli 1970) and placed in a boiling water bath for $3 \mathrm{~min}$. The samples were sedimented at $14000 \times \mathrm{g}$ for $5 \mathrm{~min}$ in a microfuge, 
and $5 \mu$ aliquots of the supernatants were subjected to SDS-PAGE and transferred to nitrocellulose paper as previously reported (Griffiths et al. 1991). Samples of $50 \mathrm{ng}$ (by dry wt) of extracellular products harvested from laboratory cultures of Renibacterium salmoninarum (Griffiths \& Lynch 1991) and pre-stained molecular mass markers (Bio-Rad Laboratories Ltd., Hercules, CA, USAl were included on each SDSPAGE gel.

For the Western blots using a monoclonal antibody, the nitrocellulose papers were washed with tris buffered saline $(10 \mathrm{mM}$ Tris-HCl, $250 \mathrm{mM} \mathrm{NaCl}$, $\mathrm{pH}$ 7.5) containing $0.05 \% \mathrm{v} / \mathrm{v}$ Tween-20 (TTBS) for $30 \mathrm{~min}$. All subsequent binding agent steps were conducted in a total volume of $10 \mathrm{ml}$ of TTBS. The first binding agent was a $5 \times 10^{-2}$ dilution of ascites fluid containing a monoclonal antibody reactive with the Renibacterium salmoninarum p57 antigen (kindly provided by F. Markham, Atlantic Veterinary College, Charlottetown, PEI, Canada) (60 min incubation), the second was $5 \times 10^{-3}$ dilution of biatinylated goat antimouse immunoglobulin (Pierce, Rockford, IL, USA) ( 30 min incubation), and the third was a $3 \times 10^{-3}$ dilution of streptavidin alkaline phosphatase (Amersham Corp., Arlington Heights, IL) (15 min incubation). Each binding agent step was followed by 2 washes with TTBS for $5 \mathrm{~min}$. Colour development of the blots was as previously reported (Griffiths et al. 1991). All incubations and washes were performed using a Western roller TM, Model 106 (Biocomp Instruments Inc., Fredericton, NB).

\section{RESULTS}

\section{Detection of Renibacterium salmoninarum in kidney tissue and ovarian fluid}

In 1992, culture from kidney tissue identified the highest number of female Atlantic salmon broodstock infected with Renibacterium salmoninarum (34.5\%; Table 1). Other methods used to analyze kidney tissue identified lower numbers of infected fish: 12\% by IFAT, $4 \%$ by ELISA, and $1 \%$ by the Western blot assay. Analysis of ovarian fluid samples collected from the same fish produced $19.5 \%$ positive by culture, $7.5 \%$ positive by IFAT and $0 \%$ positive by ELISA. (Due to the low sensitivity of the Western blot assay only 35 ovarian fluid samples were tested and all were negative.)

The correlations between the BKD detection methods and between detection of Renibacterium salmoninarum in kidney tissue and ovarian fluids are shown in Table 1. A total of 91 of the 200 fish tested positive where the results for all of the assay methods on kidney tissue and ovarian fluid were considered. Of these 91 fish each method identified the following: $76 \%$ by kidney culture, $43 \%$ by ovarian fluid culture, $26 \%$ by kidney IFAT, $14 \%$ by ovarian fluid IFAT, $9 \%$ by kidney ELISA, $2 \%$ by kidney Western blot, and $0 \%$ by ovarian fluid ELISA. Interestingly, 37 of these 91 fish were identified only by kidney culture, 15 were identified only by ovarian fluid culture, 3 were identified only by kidney IFAT, and 2 were identified only by ovarian fluid IFAT.

Table 1 Comparison of methods to detect Renibacterium salmoninarum in ovarian fluids and kidney tissue from broodstock Atlantic salmon collected in 1992

\begin{tabular}{|c|c|c|c|c|c|c|c|c|}
\hline \multirow{2}{*}{\multicolumn{2}{|c|}{$\begin{array}{l}\text { No. of fish } \\
\text { sampled }\end{array}$}} & \multicolumn{4}{|c|}{ Kidney } & \multicolumn{3}{|c|}{ Ovarian fluid } \\
\hline & & $\begin{array}{l}\text { Culture on } \\
\text { SKDM agar }\end{array}$ & $\begin{array}{c}\text { IFAT } \\
\text { technique }\end{array}$ & ELISA & $\begin{array}{l}\text { Western } \\
\text { blot assay }\end{array}$ & $\begin{array}{l}\text { Culture on } \\
\text { SKDM agar }\end{array}$ & $\begin{array}{c}\text { IFAT } \\
\text { technique }\end{array}$ & ELISA \\
\hline & 109 & - & - & - & - & - & - & - \\
\hline & 37 & + & - & - & - & - & - & - \\
\hline & 15 & - & - & - & - & + & - & - \\
\hline & 8 & + & - & - & - & + & - & - \\
\hline & 5 & + & + & - & - & - & - & - \\
\hline & 3 & + & + & + & - & - & - & - \\
\hline & 3 & + & + & - & - & + & + & - \\
\hline & 3 & + & + & - & - & + & - & - \\
\hline & 3 & - & + & - & - & - & - & - \\
\hline & 3 & + & - & - & - & + & + & - \\
\hline & 2 & + & + & + & + & + & + & - \\
\hline & 2 & + & + & + & - & + & - & - \\
\hline & 2 & + & - & - & - & - & + & - \\
\hline & 2 & - & + & - & - & + & + & - \\
\hline & 2 & - & - & - & - & - & + & - \\
\hline & 1 & + & + & + & - & + & + & - \\
\hline Totals 2 & 200 & $69(34.5 \%)$ & $24(12 \%)$ & $8(4 \%)$ & $2(1 \%)$ & $39(19.5 \%)$ & $15(7.5 \%)$ & $0(0 \%)$ \\
\hline
\end{tabular}


It is possible that not all subclinically infected female fish produced ovarian fluids containing viable Renibacterium salmoninarum (i.e. bacteria may have been present in one tissue sample but not the other) because 47 of the 69 fish positive by kidney culture produced ovarian fluid that yielded negative results by culture However, 17 of the 39 culture-positive ovarian fluids were collected from fish whose kidneys produced negative results by culture. We suspected that a significant number of ovarian fluids containing low levels of $R$. salmoninarum may not have been identified by the methods used.

\section{Growth enrichment in SKDM broth combined with Western blotting}

An additional method involving culture of ovarian fluid cellular debris in SKDM broth followed by Western blotting of the cultured material was used to screen ovarian fluid samples collected in 1993.

Positive ovarian fluid samples, following incubation in SKDM broth, were rapidly identified by Western blotting which detected a major immunoreactive band (Fig. 1, lanes 1, 4 and 6) corresponding to the p57 protein of $R$. salmoninarum (Fig. 1, lane 12). Despite the use of a monoclonal antibody reactive with p57, other bands from the ovarian fluid samples were found to be reactive at varying degrees of intensity in the Western blot assay. These bands even occurred in the absence of a detectable p57 band (Fig. 1, lanes 2, 3, 5, 7-9; and Fig. 2A, lanes $2,4-6$ ). These reactive bands appeared to be due to non-specific cross-reaction of ovarian fluid proteins and/or SKDM components with the secondary biotinylated antibody and streptavidin alkaline phosphatase because, unlike the p57 band, they tended to occur even when the primary $p 57$ monoclonal antibody was omitted from the Western blot assay (Fig 2B). These non-specific reactions did not pose any hindrance to the interpretation of the Western blot results. Positive ovarian fluid samples contained insufficient p57 antigen to be detected prior to their incubation in SKDM broth (Fig. 2A).

Multiple bands (other than p57) observed in the extracellular products harvested from Renibacterium salmoninarum SKDM agar cultures (Fig. 1, lane 12) were due to reaction of the monoclonal antibody with proteolytic degradation products and complexes of p57 that form in concentrated extracellular products (Griffiths \& Lynch 1991, Rockey et al. 1991, Wiens \& Kaatari 1991).

Attempts to isolate and identify Renibacterium salmoninarum colony-forming units on SKDM agar subsequent to incubation of the ovarian fluid samples (both positive and negative) in SKDM broth were precluded by the presence of ather faster growing microorganisms which presumably had increased in numbers during incubation in the SKDM broth

\section{Comparison of the growth enrichment/Western blot assay with culture on SKDM agar and IFAT}

Culture on SKDM agar and IFAT were used as the established methods to screen 601 ovarian fluid samples (kidney samples were not made available)

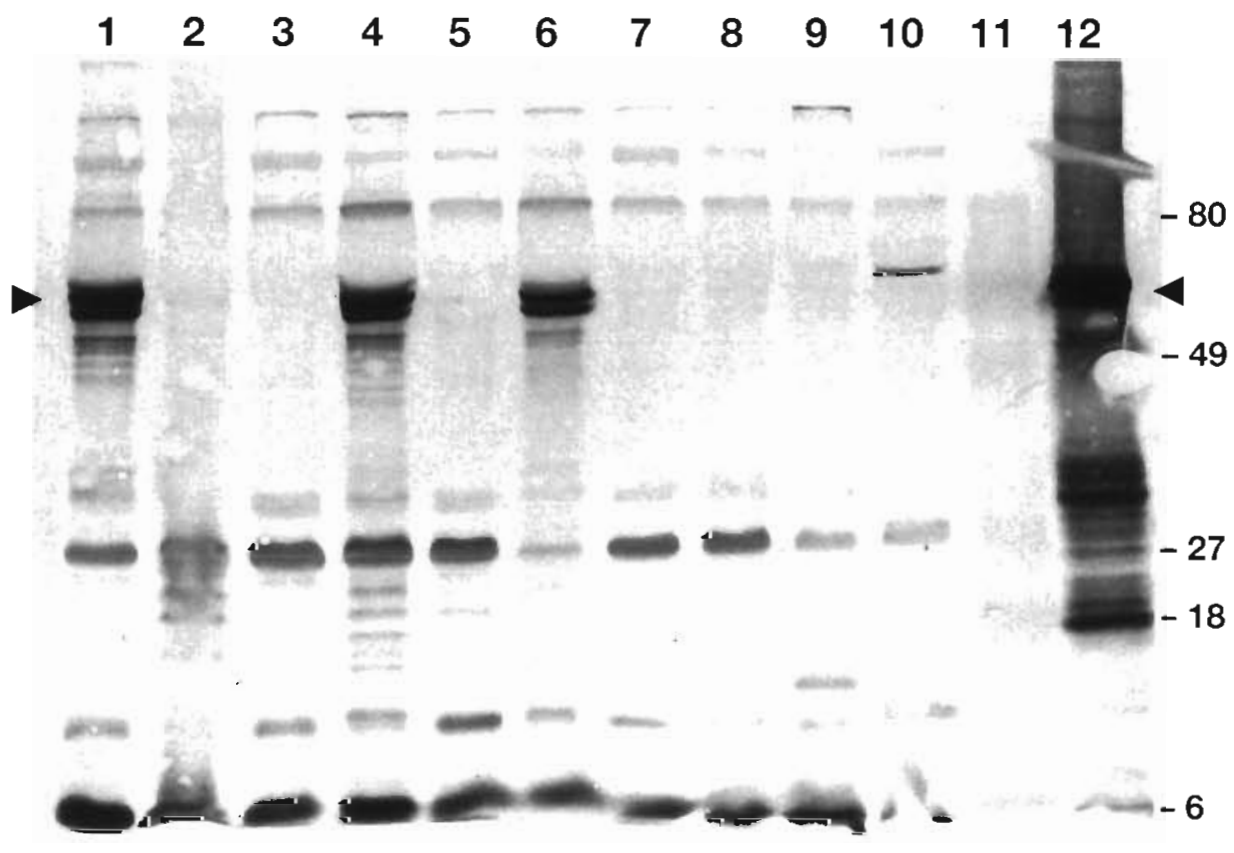

Fig. 1. Western blot detection of the Renibacterium salmoninarum major soluble antigen (indicated by arrowheads) following incubation of ovarian fluid cellular debris in selective kidney disease broth medium. Ovarian fluid samples positive (lanes 1,4 , and 6), weakly positive (lane 10), and negative (lanes 2, 3, 5, and 7-9) for the $R$, salmoninarum major antigen. Pre-stained molecular mass markers are shown in lane 11 and extracellular products from a laboratory culture of $R$. salmoninarum are shown in lane 12 
A

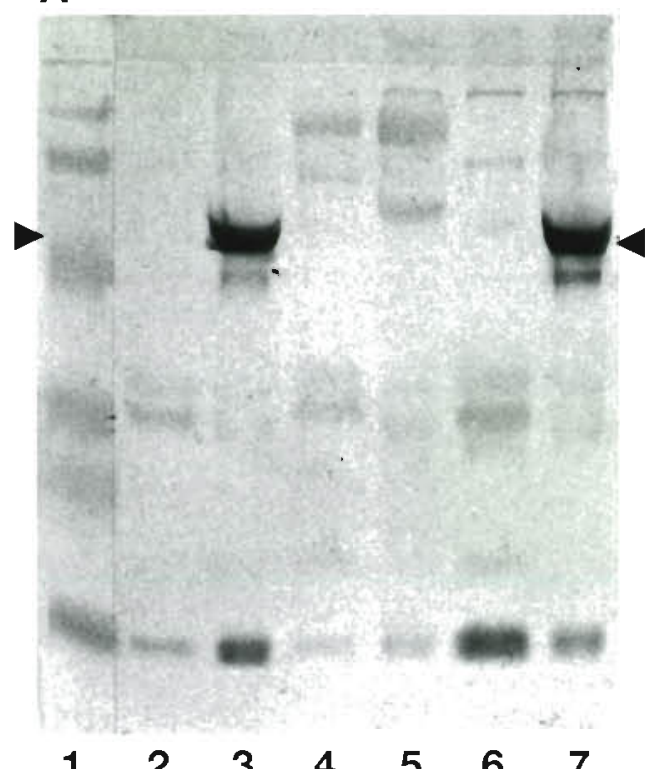

B

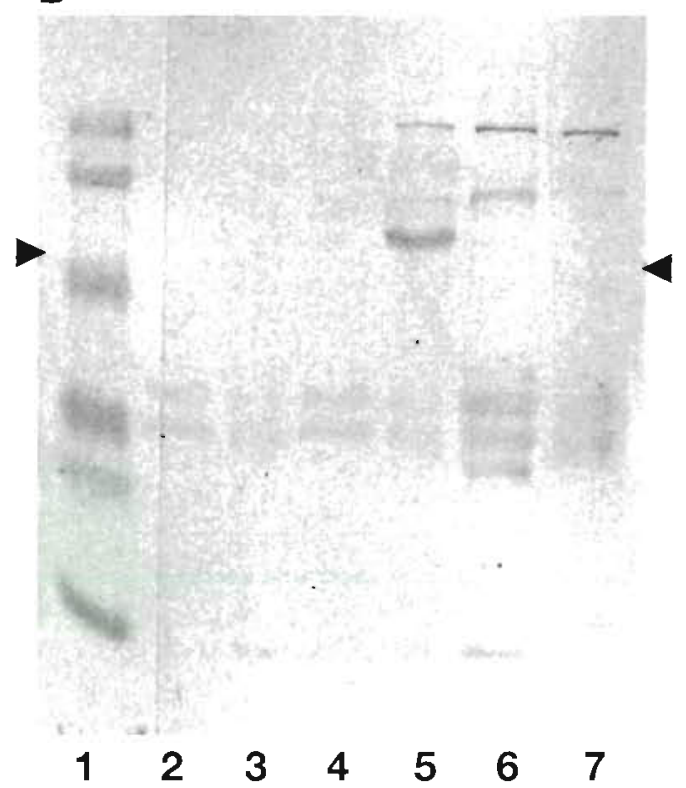

Fig. 2. (A) Western blot detection of the Renibacterium salmoninarum major soluble antigen (indicated by arrowheads) in ovarian fluid cellular debris samples before (lanes 2,4, and 6) and after incubation of the same samples in selective kidney disease broth medium (lanes 3, 5, and 7). Incubated ovarian fluid samples positive (lanes 3 and 7) and negative (lane 5) for the $R$ salmoninarum major antigen. (B) Same samples as in (A) except that the monoclonal anti-p57 antibodies were omitted from the Western blot assay. Lanes 1 of (A) and (B) contained pre-stained molecular mass standards

obtained from 6 farms in the Bay of Fundy in 1993 and the results obtained were compared to those obtained using growth enrichment in SKDM broth followed by Western blotting (Table 2). The number of ovarian fluids positive for Renibacterium salmoninarum by the methods tested ranged from 0 to $36.6 \%$, depending on the farm from which the samples were collected. A total of 75 of the 601 samples tested positive. Of these positive samples, more were identified by a combination of growth enrichment and Western blotting (50) than by culture on SKDM agar (39) or IFAT (36).

A comparison between the methods (Table 3) showed that only $19 \%$ of the positive ovarian fluid samples produced a positive result by all 3 methods and only $48 \%$ of the positive samples gave a positive result by 2 or more of the methods. These results emphasized the inadequacy of any single method for identifying all ovarian fluid samples containing Renibacterium salmoninarum.

\section{DISCUSSION}

A high prevalence $(34.5 \%)$ of subclinical BKD infection was detected in 200 post-spawned female broodstock Atlantic salmon in 1992 by culture of Renibacterium salmoninarum from kidney tissue samples on SKDM agar. However, for many of the individual fish,

Table 2. Detection of Renibacterium salmoninarum in ovarian fluid samples collected in 1992 from broodstock Atlantic salmon from 6 farms

\begin{tabular}{|c|c|c|c|c|c|}
\hline \multirow{2}{*}{ Farm site } & \multirow{2}{*}{$\begin{array}{c}\text { No. of } \\
\text { samples }\end{array}$} & \multicolumn{3}{|c|}{$\ldots$ No. of samples positive ___ } & \multirow{2}{*}{$\begin{array}{l}\text { Percentage of samples } \\
\text { positive by the } \\
\text { methods tested }\end{array}$} \\
\hline & & $\begin{array}{c}\text { IFAT } \\
\text { technique }\end{array}$ & $\begin{array}{l}\text { Culture on } \\
\text { SKDM agar }\end{array}$ & $\begin{array}{l}\text { Growth enrichment } \\
\text { with Western blot assay }\end{array}$ & \\
\hline A & 60 & 0 & 0 & 0 & 0 \\
\hline $\mathrm{B}$ & 90 & 1 & 2 & 5 & 6.7 \\
\hline $\mathrm{C}$ & 169 & 0 & 0 & 6 & 3.6 \\
\hline $\mathrm{D}$ & 139 & 13 & 17 & 24 & 19.3 \\
\hline$E$ & 60 & 4 & 0 & 2 & 10 \\
\hline $\mathrm{F}$ & 82 & 18 & 20 & 13 & 36.6 \\
\hline Totals & 601 & 36 & 39 & 50 & 12.5 \\
\hline
\end{tabular}


Table 3. Comparison of methods to detect Renibacterium salmoninarum in ovarian fluid samples from broodstock Atlantic salmon collected in 1992

\begin{tabular}{|cccc|}
$\begin{array}{c}\text { No. of } \\
\text { samples }\end{array}$ & $\begin{array}{c}\text { IFAT } \\
\text { technique }\end{array}$ & $\begin{array}{c}\text { Culture on } \\
\text { SKDM agar }\end{array}$ & $\begin{array}{c}\text { Growth enrichment } \\
\text { with Western blot assay }\end{array}$ \\
526 & - & - & - \\
18 & - & - & + \\
14 & + & + & + \\
14 & - & + & + \\
14 & + & - & - \\
7 & - & + & - \\
4 & + & + & + \\
4 & + & 39 & 50 \\
\hline
\end{tabular}

by any one method $(89,64$, and $61 \%$, respectively, for SKDM agar culture, culture in SKDM broth with Western blotting and IFAT) also were scored positive by at least one other method. For immunoassays (IFAT, ELISA or Western blot assay), false-positive reactions caused by cross-reactions with antigens other than those from Renibacterium salmoninarum are possible (Austin et al. 1985, Yoshimura et al. 1987, Foott et al. 1992, Bandin et al. 1993, Brown et al. 1994). However, with the use of the monoclonal antibody to detect and positionally locate the $R$. salmoninarum p57 antigen on Western blots the possibility of false-positives

R. salmoninarum was cultivated from only 1 of the 2 tissues tested (kidney tissue or ovarian fluid). These disparities between kidney and ovarian fluid from the same fish may relate to the low levels of viable $R$. salmoninarum cells in tissues of many of the subclinically infected fish and to the difficulties associated with their successful culture from such tissues (Evelyn 1977, Daly \& Stevenson 1988, Evelyn \& Prosperi-Porta 1989).

IFAT identified fewer of the infected tissue samples than culture on SKDM agar using either kidney or ovarian fluid samples; this was consistent with earlier observations by Armstrong et al. (1989) and Griffiths et al. (1991). However, a few IFAT-positive, culturenegative tissue samples were recorded. It is possible that these results were due to tissue samples containing Renibacterium salmoninarum cells that were nonviable or in a form unable to grow on the SKDM agar under the conditions used. Another possibility is that the cell shapes identified by IFAT were other bacteria which cross-reacted with the polyclonal antiserum used (Austin et al. 1985, Yoshimura et al. 1987, Foott et al. 1992). The low sensitivities of $R$, salmoninarum detection using the ELISA or the Western blot assay, even when compared to IFAT, suggested that the amount of soluble antigen present in many samples was very low. This observation further suggests that low numbers of relatively inactive $R$. salmoninarum cells occurred in the kidney tissue and ovarian fluid of most of the subclinically infected fish tested (Lovely et al. 1994).

In 1993, the cultivation of ovarian fluids in SKDM broth followed by Western blotting detected more samples positive for Renibacterium salmoninarum than either SKDM agar culture or IFAT and increased the total number of positive samples by $32 \%$. These results suggested that a significant number of ovarian fluids containing live pathogen escaped detection by the established methods.

Incomplete correlation between the 3 methods was observed, but most of the ovarian fluids scored positive should be minimized. On the other hand, several SKDM agar culture-positive ovarian fluids were scored negative by the SKDM broth culture/Western blot technique. It is possible that some ovarian fluid samples contained very few $R$. salmoninarum cells and that not all aliquots from the same sample contained live pathogen. Other factors influencing pathogen growth may have included unidentified inhibitory components present in the ovarian fluid cellular debris and/or produced during the growth of other microorganisms (Evelyn 1977, Daly \& Stevenson 1988, Evelyn \& Prosperi-Porta 1989). Difficulties with the culture of live pathogen may indicate that ovarian fluids scoring positive by IFAT but negative by the culture may still contain live $R$. salmoninarum.

In the local management of BKD screening programs a 'zero tolerance' attitude is often adopted as standard policy (S. Roach, General Manager, Stolt Sea Farm, Saint John, NB, pers. comm.). Our results indicate that for screening it would be most advantageous to use a combination of methods (eg. SKDM broth culture with Western blot, SKDM agar culture, and IFAT) to increase the number of ovarian fluid samples containing Renibacterium salmoninarum that are identified. Future assays for $\mathrm{BKD}$ monitoring will probably involve the targeting of specific stretches of $R$. salmoninarum DNA using the polymerase chain reaction (PCR) (Brown et al. 1994, Leon et al. 1994), and it is possible these assays will provide a more sensitive method for detecting $R$. salmoninarum.

Acknowledgements. This research was supported in part by the New Brunswick Department of Economic Development and Commerce, the Natural Sciences and Engineering Council of Canada, the New Brunswick Salmon Growers Association, the Canada Department of Industry Science and Technology, the Department of Fisheries and Oceans (AFAP no. A93-NR307), and by Stolt Sea Farm Canada, Inc. The authors gratefully acknowledge the capable technical assistance of L. Hutchin, M. Adams, J. Leger, and K. Melville (all of the Research and Productivity Council of New Brunswick). 


\section{LITERATURE CITED}

Armstrong RD, Martin SW, Evelyn TPT, Hicks B, Dorward WJ, Ferguson HW (1989) A field evaluation of an indirect fluorescent antibody-based broodstock screening test used to control the vertical transmission of Renibacterium salmoninarum in chinook salmon (Oncorhynchus tshawytscha). Can J Vet Res 53:385-389

Austin B, Bucke D, Feist S, Rayment J (1985) A false positive reaction in the indirect fluorescent antibody test for Renibacterium salmoninarum with a 'coryneform' organism. Bull Eur Ass Fish Pathol 5:8-9

Austin B, Embly TM, Goodfellow M (1983) Selective isolation of Renibacterium salmoninarum. FEMS Microbiol Lett 17 $111-114$

Bandin I, Santos Y, Barja JL, Toranzo AE (1993) Detection of a common antigen among Renibacterium salmoninarum Corynebacterium aquaticum, and Carnobacterium piscicola by the Western blot technique. $J$ aquat Anim Health 5:172-176

Benediktsdottir E, Helgason S, Gudmundsdottir S (1991) Incubation time for the cultivation of Renibacterium salmoninarum from Atlantic salmon, Salmo salar L., broodfish. J Fish Dis 14:97-102

Brown LL, Iwama GK, Evelyn TPT, Nelson WS, Levine RP (1994) Use of the polymerase chain reaction (PCR) to detect DNA from Renibacterium salmoninarum within individual salmonid egos. Dis aquat Org 18:165-171

Bullock GL, Stuckey HM (1975) Fluorescent antibody identification and detection of the Corynebacterium causing kidney disease of salmonids. J Fish Res Bd Can 32:224-227

Daly JG. Stevenson RMW (1988) Inhibitory effects of salmonid tussue on the growth of Renibacterium salmoninarum. Dis aquat Org 4:169-171

Elliott DG, Barila TY (1987) Membrane filtration-fluorescent antibody staining procedure for detecting and quantifying Renibacterium salmoninarum in coelomic fluid of chinook salmon (Oncorhynchus tshawytscha). Can J Fish Aquat Sci 44:206-210

Evelyn TPT (1977) An improved growth medium for the kidney disease bacterium and some notes on using the medium. Bull Off Int Epizoo 87:511-513

Evelyn TPT, Ketcheson JE, Prosperi-Porta L (1984) Further evidence for the presence of Renibacterium salmoninarum in salmonid eggs and for the failure of povidine-iodine to reduce the intra-ovum infection rate in water-hardened eggs. J Fish Dis 7:173-182

Evelyn TPT, Prosperi-Porta L (1989) Inconsistent performance of KDM2, a culture medium for the kidney disease bacterium Renibacterium salmoninarum due to variation in the composition of its peptone ingredient. Dis aquat Org $7: 227-229$

Responsible Subject Editor: T. Evelyn, Nanaimo British Columbia, Canada
Evelyn TPT, Prosperi-Porta L, Ketcheson JE (1986) Experimental intra-ovum infection of salmonid eggs with Renibacterium salmoninarum and vertical transmission of the pathogen with such eggs despite their treatment with erythromycin. Dis aquat Org 1:197-202

Evenden AJ, Grayson TH, Gilpin ML, Munn CB (1993) Renibacterium salmoninarum and bacterial kidney disease the unfinished jigsaw. Ann Rev Fish Dis 3:87-104

Foott JS, Starliper CE, Walker RL, Junell J (1992) Pseudomonas isolate gives positive direct fluorescent antibody test using Renibacterium salmoninarum antisera. Am Fish Soc Fish Health Sect Newsletter (Bethesda, Maryland) 20(1): $2-3$

Griffiths SG, Lynch WH (1991) Instability of the major soluble antigen produced by Renibacterium salmoninarum. J Fish Dis 14:55-66

Griffiths SG, Olivier G, Fildes J, Lynch WH (1991) Comparison of Western blot, direct fluorescent antibody and dropplate culture methods for detection of Renibacterium salmoninarum in Atlantic salmon (Salmo salar L.). Aquaculture 97:117-129

Laemmli UK (1970) Cleavage of structural proteins during assembly of the head of bacteriophage T4. Nature 227 680-685

Lee EG, Evelyn TPT (1989) Effect of Renibacterium salmoninarum levels in the ovarian fluid of spawning chinook salmon: on the prevalence of the pathogen in their eggs and progeny. Dis aquat Org 7:179-184

Leon G, Maulen N, Figuerva J, Villanueva J, Rodriquez C, Ines Vera M. Krauskopf M (1994) A PCR-based assay for the identification of the fish pathogen Renibacterium salmoninarum. FEMS Microbiol Lett 115:131-136

Lovely JE, Cabo C, Griffiths SG, Lynch WH (1994) Detection of Renibacterium salmoninarum infection in asymptomatic Atlantic salmon. J aquat Anim Health 6:126-132

Olivier G, Griffiths SG, Fildes J, Lynch WH (1992) The use of Western blot and electroimmunotransfer blot assays to monitor bacterial kidney disease in experimentally challenged Atlantic salmon, Salmo salar L. J Fish Dis 15 229-241

Rockey DD, Turaga PSD, Wiens GD, Cook BA, Kaattari SL (1991) Serine proteinase of Renibacterium salmoninarum digests a major autologous extracellular and cell-surface protein. Can J Microbiol 37:758-763

Wiens GD, Kaattari SL (1991) Monoclonal antibody characterization of a leukoagglutinin produced by Renibacterium salmoninarum. Infect Immun 59:631-637

Yoshimura M, Ji R, Nomura T, Kimura T (1987) A false positive reaction in the indirect fluorescent antibody test for Renibacterium salmoninarum ATCC 33209 caused by a Pseudomonas sp. Sci Rep Hokkaido Salmon Hatchery 41 121-127

Manuscript first received: August 31, 1994

Revised version accepted: July 27, 1995 